Right to Information about, and Involvement in, Environmental Decision-Making along the Silk Road Economic Belt

\title{
Zhang, Kangle
}

2017

Zhang , K 2017 , ' Right to Information about, and Involvement in, Environmental Decision-Making along the Silk Road Economic Belt ' , The Chinese Journal of Comparative Law , vol. 5 , no. 1 , pp. 58-78 . https://doi.org/10.1093/cjcl/cxx004

http://hdl.handle.net/10138/231657

https://doi.org/10.1093/cjcl/cxx004

acceptedVersion

Downloaded from Helda, University of Helsinki institutional repository.

This is an electronic reprint of the original article.

This reprint may differ from the original in pagination and typographic detail.

Please cite the original version. 


\title{
Right to Information about, and Involvement in, Environmental Decision Making Along the Silk Road Economic Belt
}

Kangle Zhang

\begin{abstract}
The ecological vulnerability of the regions within the Silk Road Economic Belt requires environmental protection. The infrastructure-pillared structure of the Belt and legal procedures on environmental impact assessment (EIA) of various infrastructures inform the article's approach to environment protection along the Belt through the right to information about and involvement in environmental decision-making (the right to information and involvement). How to protect this right along the Belt? The rights-approach to environment, as the paper first examines, lead to an exploration of the social and historical background of the adoption of the Convention on Access TO Information, Public Participation in Decision-making and Access to Justice in Environmental Matters (Aarhus Convention) ${ }^{1}$. Parties to the Aarhus Convention largely overlap with the countries within the Belt. Critical analysis of the EIA legislation and it in practice, and the contradiction within the principle of "public participation" reveal the inadequacy of formal legislation in protecting the right to information and involvement. A case study on informal participation in environmental decision-making in China illustrates the value of informal participation in protecting this right. Informal participation is forming a communicative form of environment governance in Singapore, in which the right to information and involvement is protected. This article argues that informal participation can facilitate the protection of the right to information and involvement along the Belt.
\end{abstract}

\section{INTRODUCTION}

Critiques of both the domestic and international economic activities of People's Republic of China (PRC) largely focus on its interest-driven approach and its deprioritization of certain values, among which is environmental protection. However, the One Belt One Road (OBOR), the first published master plan on foreign affairs by the PRC- while aiming to establish a regional political structure pillared by economic-collaboration, particularly on infrastructure, uses the language of environmental protection. The Vision and Actions on Jointly Building Silk Road Economic Belt and $21^{\text {st }}$-century Maritime Silk Road (Vision and Actions) states that "efforts should be made to promote green and low-carbon infrastructure construction and operation management, taking into full

\footnotetext{
${ }^{1}$ Convention on Access to Information, Public Participation in Decision-making and Access to Justice in Environmental Matters, 1999, 38 ILM 517 (1999) (Arhus Convention)
} 
account the impact of climate change on the construction."2 The Deputy Head of the State Forestry Administration of China has highlighted "the scale of existing desertification, soil degradation, and drought in more than 60 of the 65 countries covered by the OBOR strategy"; the Chinese Academy of Social Sciences' Centre for Regional Security Studies reported that "many OBOR projects may result in a range of environmental security issues". ${ }^{3}$ At the same time, it is not surprising that within the framework of OBOR, environment protection is closely linked with economic interest, that it is treated as one of the areas for technological innovation and investment along the Belt and Road. ${ }^{4}$

The language of environment protection expresses a recognition of the environmental concerns, necessitated by the biological vulnerability along OBOR. Environmental challenges faced by the the Belt include, to list a few, complex natural features and mismanaged resources, desertification, earthquakes, biodiversity loss, and pollution within the air, water, soil and ocean. ${ }^{5}$ The openness of OBOR, ${ }^{6}$ which welcomes collaboration with further countries not necessarily within the Belt and Road, adds geographical coverage, thus increasing environmental concerns. Making use of the language of green OBOR, however, needs ideas on how to protect the environment along the Belt.

Informed by the infrastructure-pillared structure of OBOR and the legal procedure on environmental impact assessment (EIA) concerning infrastructures, this paper approaches environment protection along the Belt through the right to information about and involvement in environmental decision-making (right to information and involvement), ${ }^{7}$ and suggests that informal

\footnotetext{
${ }^{2}$ Ministry of Foreign Affairs National Development and Reform Commission, Ministry of Commerce of the People's Republic of China, with State Council authorization, Vision and Actions on Jointly Building Silk Road Economic Belt and 21st-century Maritime Silk Road (2015)

${ }^{3}$ Liu Qin, 'China's 'new Silk Road' could expand Asia's deserts' Chinadialogue (5 Sep 2016) <https://www.chinadialogue.net/article/show/single/en/9230-China-s-new-Silk-Road-could-expand-Asia-s-deserts> accessed 28 Dec 2016

${ }^{4}$ Lvy Buche Jean-Pierre Lehmann, Marc Laperrouza, Shuaihua Cheng, Lu Xiankun, Jean-Guy Carrier, Marion Jasen, Félix Sutter, Yeroen Van der Leer, 'One Belt- One Road: China's Re-Engineering of the Global Business Environment' (International Institute for Management Development 2016)

$<$ https://www.imd.org/research/insightsimd/one-belt-one-road-chinas-re-engineering-of-the-global-businessenvironment/> accessed 28 Dec 2016

${ }^{5}$ Hui Qian Peiyue Li, Ken W. F. Howard, Jianhua Wu, 'Building a new and sustainable "Silk Road Economic Belt"' (2015) 71 Environmental Earth Sciences 7267-70; Jingjing Cai Dewei Yang, Vanessa Hull, Kaiyong Wang, Yin-Phan Tsang, Jianguo Liu, 'New Road for telecoupling global prosperity and ecological sustainability' (2016) 2 Ecosystem Health and Sustainability e01242;

${ }^{6}$ The OBOR as an open instrument based on cooperation to promote the economy is reflected in the Vision and Actions.

${ }^{7}$ Right to information about and involvement in environmental decision-making is a procedural right fulfilling the right to environment. In (international) environmental law, right to environment and right of environment are put together as the environmental right, see, Dinah Shelton, 'Human Rights, Environmental Rights, and the Right to Environment' (1991-1992) 28 Standford Journal of International Law 103-38, at 105
} 
participation shall be encouraged to protect the right. ${ }^{8}$ OBOR is essentially economic-driven. Collaborations on infrastructure projects have largely advanced since the announcement of the Silk Road Initiative in 2013. The Belt has witnessed infrastructure-pillared projects, for instance the investment in gas pipeline between Myanmar and China, and the construction of three train lines between China and Europe. ${ }^{9}$ The environment impact of infrastructure projects is assessed, for the protection of the environment, through the EIA procedure which is widely incorporated in domestic legislations. ${ }^{10}$ The EIA procedure, designed to gather and study the information of environmental impacts and public comments, aims to ensure that the environmental impacts are taken into consideration when deciding whether or not to proceed with a project. Through gathering public comments, the EIA procedure seeks to protect the right of those affected to have a say in environmental decision-making. The protection of the right to information and involvement, thus, facilitates the protection of the environment when it concerns infrastructure projects.

The first part of the paper discusses the rights-approach to environmental protection. While the rights-language is, at the contemporary era, probably the best example of law as the language of both utopia and apology, ${ }^{11}$ there is an essential value in the rights language. Rights-approach to environment protection is particularly worthy of discussion in the context of the Belt given the historical and political factors along the Belt. The right to information and involvement in the context of the Belt leads the discussion to the historical background of the adoption of the Aarhus Convention, which offers insight to the social situation, in particular the vitality of NGOs, along the Belt. The second part argues that formal legislation on the protection of the right is not adequate to serve its purpose. The inadequacy is elaborated through: first, introducing a statistical analysis; second, pointing out the theoretical contradiction within the concept of "public participation". This paper gives a critical narrative of Rousseau's concept of "general will" to reveal the conceptual contradiction in "public participation", a procedural principle in (international) environmental law. The third part argues that informal participation could facilitate the protection of the right.

\footnotetext{
${ }^{8}$ Unless otherwise specified, the right in the paper refers to the right to information about and involvement in environmental decision-making.

${ }^{9}$ Dewei Yang, 'New Road for telecoupling global prosperity and ecological sustainability'

${ }^{10}$ Zhang Ge Jess L. Moorman, 'Promoting and Strengthening Public Participation in China's Environmental Impact Assessment Process: Comparing China's EIA Law and U.S. NEPA' (2007) 8 Vermont Journal of Environmental Law 281-335; Sverker Molander Abdul-Sattar Nizami, Zaki-ul-Zaman Asam, Rashid Rafique, Nicholas E. Korres, Gerard Kiely, Jerry D. Murphy, 'Comparative analysis using EIA for developed and developing countries: case studies of hydroelectric power plants in Pakistan, Norway and Sweden' (2011) 18 International Journal of Sustainable Development \& World Ecology 134-42; Thomas B. Fischer Obaidullah Nadeem, 'An evaluation framework for effective public participation in EIA in Pakistan' (2011) 3 Environmental Impact Assessment Review 36-47

${ }^{11}$ Martti Koskenniemi, 'From apology to Utopia : the structure of international legal argument' (2005)
} 


\section{THE RIGHTS APPROACH TO ENVIRONMENT PROTECTION ALONG THE BELT The rights-approach and environmental right}

At the end of the year 2016 when I was finishing the paper, I woke up one morning reading the frustrating news of the bombing of Aleppo and the violation of human rights there. Petman writes in the beginning of Human Rights and Violence, quoting an e-mail message to her: "I am... referring to the acts of torture in Iraq. I find those acts, like Guantánamo, stupefyingly obscene”, and questions "what is international law for? What are human rights for?". ${ }^{12}$ Indeed, one cannot stop but wonder, if the human rights approach was so effective, producing declarations, conventions and other instruments protecting the human rights, how is it possible that the Aleppo bombing, the refugee crisis in 2016, among many other frustrating events, are still taking place on an ongoing base? Also, the rights enlisted explicitly in conventions, for instance the Convention for the Protection of Human Rights and Fundamental Freedoms (European Court of Human Rights), are indeterminate in practice, ${ }^{13}$ adding to the dubious nature of rights approach. The doctrine of margin of appreciation leaves the space for manoeuvre to national authorities, leading to varying degrees of protection of same rights in different countries under the framework of European Court of Human Rights. ${ }^{14}$ For instance, for the issue of assisting to suicide, the European Court of Human Rights considers it within the margin of appreciation of local authorities to decide whether the forbiddance, in some cases, ${ }^{15}$ of assistance to suicide is a violation of the right to life of the individual requesting such assistance. Are the legal institutions established in order to protect human rights as determinant and effective in practice as international lawyers tend to believe?

Needless to say, the achievement of human rights, particularly of it in international legal development and practice, deserves much recognition. While Segunpta's conception of the right to development might seem overly idealistic, ${ }^{16}$ and De Wet's hope on the constitutionalization of

\footnotetext{
${ }^{12}$ Jarna Petman, Human rights and violence : the hope and fear of the liberal world (Hart Publishing, [Place of publication not identified] 2014) at 1

${ }^{13}$ The four categories as Jarna Petman presents, of European Convention of Human Rights in practice: an 'everyone' or an 'Alien'; a hierarchy of relationship; married (for) life; the meaning of life, illustrate the indeterminacy of human rights in practice under the European Convention of Human Rights with case studies; see, Petman, Human rights and violence : the hope and fear of the liberal world, at 148-82

${ }^{14}$ Yuval Shany, 'Toward a General Margin of Appreciation Doctrine in International Law?' (2005) 16 European Journal of International Law 907-40

${ }^{15}$ Pretty v. The United Kingdom (European Court of Human Rights) 2346/02

${ }^{16}$ Arjun Sengupta, 'Right to Development as a Human Right' (2001) 36 Economic and Political Weekly 2527-36
} 
international law being too optimistic, ${ }^{17}$ both of them provide us with a long list of achievements of international law, and in particular, human rights law.

Environmental protection and human rights are different issues, yet the social values they represent are overlapping, enabling an environmental rights approach. ${ }^{18}$ The right to environment was recognized as early as 1972 in the Stockholm Declaration, as Principle 1 claims: \

"Man has the fundamental right to freedom, equality and adequate conditions of life, in an environment of a quality that permits a life of dignity and well-being, and he bears a solemn responsibility to protect and improve the environment for present and future generations." Article 24 of the African Charter of Human and Peoples Rights reads: "All peoples shall have the right to a general satisfactory environment favorable to their development". Article 1 of the Convention on Access to Information, Public Participation in Decision-Making and Access to Justice in Environmental Matters (Aarhus Convention) recognizes the "right of every person of present and future generations to live in an environment adequate to his or her health or wellbeing".

Among the various rights to environment, the right to participate in environment decisionmaking expresses the value that whoever that may be affected should "have a say in the determination of their environmental future" ${ }^{" 19}$. This right is recognized in various environmental conventions and documents. To list a few, Art.41 (i) of The United Nations

Framework Convention on Climate Change obliges parties to promote public awareness and to "encourage the widest participation in this process including that of non-governmental organizations"; Art.14(1)(a) of the Convention on Biological Diversity explicitly connects environmental impact assessment with public participation; ${ }^{20}$ Agenda 21, the plan of action adopted at the Rio Conference in 1992, emphasizes that "one of the fundamental prerequisites for the achievement of sustainable development is broad public participation in decision-making"; the Rio Declaration notices that "environmental issues are best handled with participation of all concerned citizens"; Art.14 of the Protocol on Pollutant Release and Transfer Registers (Kiev Protocol) recognizes that "each party shall... ensure that any person considers that his or her request for

\footnotetext{
${ }^{17}$ Erika De Wet, 'The Constitutionalization of Public International Law' in AS Michel Rosenfelf (ed), The Oxford Handbook of Comparative Constitutional Law (Oxford University Press, Oxford 2012) 1209-30

${ }^{18}$ Shelton, 'Human Rights, Environmental Rights, and the Right to Environment', at 104-5

${ }^{19}$ Alexandre Charles Kiss and Dinah Shelton, Guide to international environmental law (Martinus Nijhoff Publishers, Leiden; Boston 2007) at 102

${ }^{20}$ Art. 14 (1)(a) reads, "1. Each Contracting Party, as far as possible and as appropriate, shall: (a) Introduce appropriate procedures requiring environmental impact assessment of its proposed projects that are likely to have significant adverse effects on biological diversity with a view to avoiding or minimizing such effects and, where appropriate, allow for public participation in such procedures"
} 
information... has access to a review procedure before a court of law...”. Adding to the recognition and protection of this particularly right in various international, multilateral and bilateral instruments, ${ }^{21}$ the right to participate is also recognized by regional human rights courts through incorporating this right into the framework of related rights. For example, the European Court of Human Rights ruled in Guerra and Others v. Italy, ${ }^{22}$ that concerning the chemical factory producing fertilizers where the applicants lived, the inaccessibility of essential information on environmental risks constitute a violation of Article 8, the "Right to respect for private and family life", of European Convention on Human Rights.

With the right to participate in environmental decision-making incorporated in various legal instruments, it is explicitly elaborated in the Aarhus Convention, that it includes the "access to environmental information", "public participation in environmental decision making", and "access to justice" (the three pillars). ${ }^{23}$ This paper limits the scope of inquiry to the first two pillars of the three listed in Aarhus Convention, namely the right to information about the involvement in environmental decision-making (the right).

Aarhus Convention is particularly relevant in the context of OBOR. Though China is not a party to the Convention, the geographical coverage of the Silk Road Economic Belt is overlapping, by a huge percentage, with the parties to the Aarhus Convention. ${ }^{24} 25$ of the 47 parties to the Aarhus Convention are along the Belt and Road: ${ }^{25}$ Albania, Armenia, Azerbaijan, Belarus, Bosnia and Herzegovina, Bulgaria, Croatia, Czech Republic, Estonia, Georgia, Hungary, Kazakhstan, Kyrgyzstan, Latvia, Lithuania, Montenegro, Poland, Republic of Moldova, Romania, Serbia, Slovakia, Slovenia, Tajikistan, Turkmenistan, Ukraine; 18 of the 47 have either participated or shown interest in OBOR by May 2016: Austria, Belgium, Cyprus, Denmark, Finland, France, Germany, Greece, Iceland, Italy, Malta, The Netherlands, Norway, Portugal, Spain, Sweden, Switzerland, United Kingdom. ${ }^{26}$ Several countries in Central and West Asia, the original target of

\footnotetext{
${ }^{21}$ A detailed account of account of international instruments concerning the right to information about and involvement in decision-making is provided in, Dinah Shelton Donald K. Anton, Environmental protection and human rights (Cambridge University Press, New York 2011) at 381

${ }^{22}$ Guerra and Others v. Italy (European Court of Human Rights) 14967/89

${ }^{23}$ Stuart Bell and Donald McGillivray, Environmental law (Oxford University Press, Oxford; New York 2008) at 294; Leslie-Anne Duvic-Paoli, 'The Status of the Right to Public Participation in International Environmental Law: An Analysis of the Jurisprudence' (2013) 23 Yearbook of International Environmental Law 80-105

${ }^{24}$ Map of the parties to the Aarhus Convention <https://www.unece.org/env/pp/aarhus/map.html> accessed 26 Dec 2016

${ }^{25}$ UNECE, 'Status of ratification of Aarhus Convention' (<https://www.unece.org/env/pp/ratification.html> accessed 28 Dec 2016

${ }^{26} 65$ countries along the Belt and Road, and 48 countries that have either participated or shown interest in the Belt and Road Initiative, by May 2016, is provided in, Winnie He Helen Chin, 'The Belt and Road Initiative: 65
} 
the Silk Road Initiative when introduced in $2013,{ }^{27}$ are parties to the Aarhus Convention, including Armenia, Azerbaijan, Georgia, Kazakhstan, Kyrgyzstan, Tajikistan and Turkmenistan. The Aarhus Convention obliges parties to adopt legislation that matches the requirements of the Convention, and promotes domestic legislations on the three pillars mentioned above. It is foreseeable that infrastructure and other projects of the Belt in a vast number of countries will encounter national legislations, which are obliged by the Aarhus Convention to set up procedures for the protection of the right to information and involvement. ${ }^{28}$

\section{Adoption of Aarhus Convention: the social and historical context}

The indeterminacy of the rights in practice informs a cautious view on the historical and social context which contributed to the codification of the rights. Concerning the right to information and involvement incorporated in Aarhus Convention, this part introduces the social and historical context of the adoption of Aarhus Convention. The Aarhus Convention was negotiated under the auspices of the United Nations Economic Commission for Europe (UNECE). UNECE, set up in 1947 by United Nations Economic and Social Council (ECOSOC), aims to promote pan-European economic integration. ${ }^{29} \mathrm{~A}$ whole body of international environmental laws covering trans-boundary aspects of air pollution, access to safe drinking water and adequate sanitation, release of hazardous chemicals, climate change, effective engagement of the public in decision-making and access to environmental information and justice, was developed by UNECE. ${ }^{30}$ In 1991, after the collapse of the Soviet Union and the drastic social changes in Eastern Europe, the Environment for Europe process to promote pan-European environmental cooperation was co-initiated by UNECE. The Environment for Europe discussions "served as the immediate backdrop for the two years of

Countries and Beyond' <https://www.fbicgroup.com/?q=publication/belt-and-road-initiative-65-countries-andbeyond> accessed 28 Dec 2016

${ }^{27}$ European Parliament Think Tank, 'One Belt, One Road (OBOR): China's regional intergration initiative' <http://www.europarl.europa.eu/thinktank/en/document.html?reference=EPRS_BRI(2016)586608> accessed 28 Dec 2016

${ }^{28}$ While such an encounter entails another research topic, namely comparative studies on the national legislations on the protection of the right to information and involvement along the Belt, in particular difference between party members to and not to Aarhus Convention, it exceeds the agenda of this paper which is to reveal the inadequacy of the existing legislations protecting the right, and encouraging informal participation. That said, this paper hopes to encourage further studies comparing national legislations on the protection of the right of countries along the Belt and Road.

${ }^{29}$ UNECE includes 56 member States in Europe, North America and Asia, see, UNECE, 'Member States and Member States Representatives' (<http://www.unece.org/oes/nutshell/member_States_representatives.html〉 accessed 28 Dec 2016

${ }^{30}$ UNECE, 'Environmental Policy' (<https://www.unece.org/env/welcome.html> accessed 28 Dec 2016 
negotiations that produced the Aarhus Convention, and it was at the Fourth Ministerial Conference (in Aarhus, Denmark in June 1998) under this process that the Convention was adopted". ${ }^{31}$

The Aarhus Convention was considered remarkable in the context of external democracy promotion. 32 "Between 1990 and 1995, 16 newly independent Central and Eastern European states had joined UNECE and, at least symbolically, were keen to embrace democratic values". 33 "From 1989 both the European Commission and the US funded major governmental and nongovernmental capacity-building programs in the former communist countries". ${ }^{34}$ UNECE fuses environmental protection with the promotion of democratic values in the Environment for Europe process through sparkplugging the procedural right, which was then incorporated in Aarhus Convention. As Mason observes, "the ambitious multilateralism of UNECE in regard to the pan-European development of environmental information disclosure cannot be divorced from its democracy promotion efforts in Central and Eastern Europe." ${ }^{35}$ One result of this process was the increased role of nongovernmental organizations and environmental activists throughout the process of the transitional period in 1980s and 90s, forming strong civil societies both domestically and in the whole region of Central Asia.

Such a historical and social background presents the active role of the civil society in the region of Central Asia. While Aarhus Convention is taken, nowadays, as the convention protecting principle rights, ${ }^{36}$ the process of the adoption of the Convention offers insights into the social situation in Central Asia, thus providing information of the social background in protecting the right to information and involvement in the region.

\section{RIGHT TO INFORMATION AND INVOLVEMENT INADEQUATELY PROTECTED}

The informal and cooperative structure of the Belt leads to a heavy reliance on local and regional rules. The Aarhus Convention protect the right to information and involvement by obliging parties to adopt formal legislations to protect the right. The protection of the right is eventually provided at

\footnotetext{
${ }^{31}$ Michael Mason, 'Information Disclosure and Environmental Rights: The Aarhus Convention' (2010) 10 Global Environmental Politics 10-31, at 12

${ }^{32}$ Barbara Jancar-Webster, 'Environmental Movement and Social Change in the Transition Countries' in PJ Susan Baker (ed), Dilemmas of transition : the environment, democracy and economic reform in East Central Europe (Frank Cass, London; Portland, OR 1998) 69-92

${ }^{33}$ Mason, 'Information Disclosure and Environmental Rights: The Aarhus Convention', at 12

${ }^{34}$ Mason, 'Information Disclosure and Environmental Rights: The Aarhus Convention', at 12

${ }^{35}$ Mason, 'Information Disclosure and Environmental Rights: The Aarhus Convention', at 12

${ }^{36}$ Sébastien Duyck, 'Promoting the Principles of the Aarhus Convention in International Forums: The Case of the UN Climate Change Regime' (2015) 22 Review of European Community \& International Environmental Law 123-38; Mohammad Hossein Ramazani Ghavamabadi Seiyed Asghar Sajjadi, 'The Element of 'Access to Information' in Aarhus Convention and Act Regarding Dissemination and Free Access to Information' (2016) 9 Journal of Politics and Law 103-24
} 
the domestic level. EIA legislations, widely adopted, seeks to protect the right. Can the existing national legislations effectively protect the right?

Formal legislations, this part argues, do not adequately protect the right. The Chinese legislation on EIA procedure and other legal instruments in China regulating the disclosure of information are introduced, first, to offer an introduction of the EIA procedure. Then, some evidences of the EIA procedure in practice shows the inadequacy of the formal legislation in protecting the right. The evidences showing the EIA inadequately protecting the right is abundantly provided in existing researches, and this paper deem some elaborations sufficient in making the point, thus will not try to exhaust the problems of EIA legislations in practice in various countries. The principle of public participation in (international) environmental law resonates with Rousseau's concept of "general will", and this part then turns to a critique of the concept of "general will" to illustrate the theoretical contradiction in public participation.

In China, the EIA procedure is provided in the Law of the PRC on Environmental Impact Assessment, which was adopted on 28 Oct, 2002, and came into effective on 1 Sep, 2003. Article 11 of the EIA law stipulates:

'As for a special plan, which may cause adverse effects on the environment and may have a direct bearing on the rights and interests of the public in respect of the environment, the authority that draw up the plan shall, before submitting the draft of the plan for examination and approval, hold demonstration meetings or hearings, or solicit in other forms the comments and suggestions from the relevant units, specialists and the public on the draft report on environmental effects, except where secrets need to be guarded as required by State regulations. The authority that draws up the plan shall seriously consider the comments and suggestions put forward by the relevant units, specialists and the public on the draft of the written report on environmental effects and attach to the written report on environmental effects to be submitted for examination its explanations on why it adopts or rejects those comments and suggestions. ${ }^{37}$

The role of the authority as the initiator when it comes to environmental decision-making exposes the top-down structure of EIA. The public authority has the right to decide what are the issues to be discussed, and through what channels the private actors shall be involved in the

\footnotetext{
${ }^{37}$ Law of the People's Republic of China on Environmental Impact Assessment $<$ http://www.npc.gov.cn/englishnpc/Law/2007-12/06/content_1382122.htm > accessed 26 Dec 2016
} 
discussions. The top-down structure of EIA, existing in the environmental legislations in many countries, has invoked criticism of EIA in general. ${ }^{38}$

\section{Evidences to the inadequately protected right}

After a brief introduction of the legislations in China protecting the right to information and involvement, this part explores the question of, are the legislations adequate in protecting this right?

One approach assessing the capacity of formal legal institutions in engaging the citizens in decision-making process is the Public Participation Index (PPI), which evaluates "the capacity of EIA public participation to influence decision-making processes". ${ }^{39}$ PPI defines a set of criteria and attributes weights to the indicators for each criterion, measuring both legislation on and practices of EIA with specific cases through the indicators. ${ }^{40}$ The criteria listed include the following: "(a) Timing; (b) Information provision; (c) Consultation arrangements; (d) Public consulted; (e) Incorporation of public participation results in the EIA report." ${ }^{41}$ Noticing that the quantitative method is vulnerable to the criticism of the contingency and indeterminacy of the criteria chose and weighting assigned, the PPI does offer a model of reference, showing the extent to which the practice of EIA protects the values and interests the legislation wishes to protect. A case study on the New Beijing Airport, with the PPI, concluded that "while public participation procedures virtually allowing the public to influence decision-making are in place, it appears that they are not used to their full potential. As a result, the process of participation appears to be dispendious, and yet ineffective." 42 This case study shows that "citizens have matured a feeling of disillusion toward institutionalized forms of public participation and legal redress, often perceived as costly and inefficient". 43

\footnotetext{
${ }^{38}$ There are several other domestic administrative document in China concenring public participation, among which the Law on Environmental Protection (Revision) adopted by the Standing Committee of National People's Congress on 24 April 2014, and came into force on 1 January 2015. Chapter V of the Revision focuses on information openness and public participation.

${ }^{39}$ Angela Moriggi Daniele Brombal, Antonio Marcomini, 'Evaluating public participation in Chinese EIA. An integrated Public Participation Index and its application to the case of the New Beijing Airport' (2017) 62 Environmental Impact Assessment Review Environmental Impact Assessment Review 49-60, at 51

${ }^{40}$ A detailed introduction of the PPI methodology, cinluding the theoretical and analytical framework, normalization, weighting and aggregation is provided in, Daniele Brombal, 'Evaluating public participation in Chinese EIA. An integrated Public Participation Index and its application to the case of the New Beijing Airport'

${ }^{41}$ Daniele Brombal, 'Evaluating public participation in Chinese EIA. An integrated Public Participation Index and its application to the case of the New Beijing Airport', at 51

${ }^{42}$ Daniele Brombal, 'Evaluating public participation in Chinese EIA. An integrated Public Participation Index and its application to the case of the New Beijing Airport', at 58

${ }^{43}$ Daniele Brombal, 'Evaluating public participation in Chinese EIA. An integrated Public Participation Index and its application to the case of the New Beijing Airport', at 58
} 
Another situation where the EIA legislation faces problems in practice is the conflict of interest between the companies producing the EIA report and the project developers in China. "EIA reports are commissioned by developers to licensed companies, whose interest lies in obtaining development consent from the competent authority". ${ }^{44}$

While the statistical analysis shows the inadequacy of protection of the right in China, studies have shown the insufficient protection of the right in other countries and regions as well. For instance, Poland, being an EU member and a party to the Aarhus Convention, ${ }^{45}$ has cases showing the lack of protection of the right to environmental information despite legislation protecting the right. An research on the "information on the date of the official adoption by the local council of the municipal environmental protection programme" shows that environmental information in some Polish municipalities is impossible to obtain. ${ }^{46}$ Another study on the mines in Poland shows that most respondents to the public opinion survey "could not assess if the legal regulation of public participation in the decision process were sufficient, but the negative opinions outweighed the positive ones". ${ }^{47}$ The implementation of the policies about biodiversity conservation and public participation by "regional, road and forestry planning sectors work" show the "gaps in planning processes... and weakly developed public participation."48

The above evidences show the inadequacy of formal legislation in protecting the right. Adding to that, the compliance to Aarhus Conventions, protecting the right, might not reach the standard of protection the convention aims at. A study on the implementation and compliance experience of Aarhus provisions on information disclosure reveals an incompleteness of Aarhus information rights, that parties are accorded the discretion in interpreting rights in Aarhus Convention, and the private entities are excluded from the obligation of information disclosure. ${ }^{49}$

\section{General will and public participation: theoretical contradictions}

This part argues that there is an embedded theoretical contradiction with the concept "public participation", a procedural principle in (international) environment law protecting the right to

\footnotetext{
${ }^{44}$ Daniele Brombal, 'Evaluating public participation in Chinese EIA. An integrated Public Participation Index and its application to the case of the New Beijing Airport', at 58

${ }^{45}$ Poland signed Aarhus Convention on 25 June 1998, and ratified on 15 February 2002.

${ }^{46}$ Pawel A. Banas, 'International ideal and local practice : access to environmental information and local government in Poland' (2010) 20 Environmental Policy and Governance, at 44

${ }^{47}$ Jaroslaw Badera and Pawel Kocon, 'Local community opinions regarding the socio-environmental aspects of lignite surface mining: Experiences from central Poland' (2014) 66 Energy Policy Energy Policy 507-16, at 507

${ }^{48}$ Per Angelstam Malgorzata Blicharska, Hans Antonson, Marine Elbakidze, Robert Axelsson, 'Road, forestry and regional planners' work for biodiversity conservation and public participation: A case study in Poland's hotspot regions' (2011) 54 J. Environ. Plann. Manage. Journal of Environmental Planning and Management 1373-95

${ }^{49}$ Mason, 'Information Disclosure and Environmental Rights: The Aarhus Convention', at 21
} 
participate, including the right to information and involvement. This contradiction results in the inadequate protection of the right. Public participation in international environmental law is a procedural principle, which requires certain arrangements to be made by public authorities to guarantee the participation in the decision-making process of those affected, including the general public, the environmental non-governmental organizations, and other actors. ${ }^{50}$ The underlying claim of "public participation", that it protects the individuals' right to participate in environmental decision-making, contradicts with the actual neglect of (groups of) individuals in the process of decision-making. According to the concept of public participation, the right to participate in environmental decision-making is protected by a procedural practice: the authority will provide the platform for the public to comment and join in the decision-making process. Public participation is essentially about the authority of decision-making: for individuals, it means the chance to join the state in making decisions that concern the environment they live in. According to the concept of public participation, the right to information and involvement is protected because the participation of those being affected in the environment expresses the will of the public. The will of the public decides, thus, what is the best for the public concerning the living environment.

The will of the public resonates with Rousseau's concept of "general will". The will of the public, in the concept of "public participation", is the will of the subject making decisions, a subject consisted of the authority and individuals. Constituted by the procedural of participation, the will of the public is based on, and for the protection of, the interest of the public. "General will" is the will of the political body as "a moral being", tending to "the conservation and well-being of the whole and of each part of it". ${ }^{51}$ The will expressed through public participation is, in the framework of Rousseau's philosophy, the general will; meanwhile, the individuals' involvement in decisionmaking through public participation is about the relationship between the individual and the state, the theme of Rousseau's arguments. Indeed Rousseau's thought is about "every issue concerning the relations between the... individual and the state". ${ }^{52}$

In the context of seventeenth and eighteenth century Europe, the two theories explaining authority's ruling, which is essentially about decision-making, were the kings' divine right to rule,

\footnotetext{
${ }^{50}$ Academy of European Law, 'Participatory and Procedural Rights in Environmental Matters' (<http://ec.europa.eu/environment/legal/law/3/module_3_1.htm> accessed 28 Dec; Duvic-Paoli, 'The Status of the Right to Public Participation in International Environmental Law: An Analysis of the Jurisprudence'; Neil A.F. Popovic, 'The Right to Participate in Decisions That Affect the Environment' (1993) 10 Pace Environmental Law Review 683-709

${ }^{51}$ Jean-Jacques Rousseau, Discourse on Political Economy and The Social Contract. Trans. C Betts (Oxford World's Classics, Oxford University Press, United States 1994) at 4

52 Jean Starobinski, translated by Peter France, Rousseau \& Modern Tyranny, The New York Review of Books, November 29, 1973
} 
and the consent of subjects to be ruled by the ruler based on a contract. The emergence of the nation-state and theories of sovereignty in Europe were not able to shake the orthodoxy belief of the kings' divine right, "a right that was seen as the origin and basis of social organization". 53

Contractual theory, opposing the kings' divine right, takes ruling as based on a contract between ruler and subjects, "by which the subjects consent to be ruled". ${ }^{54}$ Through the notion of "volonté générale" (general will) by Rousseau, seeking "to define the nature of the bond by which the group is created", the individuals are equipped with an active role in jointly producing a social pact upon which the society is constituted, and the authority of the political body derived. Rousseau's theory, being a contractual theory, differs from the traditional contractual theory for it explores the nature of the contract, and adds to the contractual theory an active role of the people, the general public. The general will is the will of the public, the people as a whole, reached at a point when "there has been unanimity". ${ }^{55}$ The unanimity produces a prior covenant, in another word, a social pact, through which "each of us puts his person and all his power in common under the supreme direction of the general will; and we as a body receive each member as an indivisible part of the whole." 56 This is an active "action of association", producing "a moral and collective body", a body that is "endowed with its unity, its common self, its life, and its will." 57

Freedom is the centre of Rousseau's theory, through which general will is constituted as the core idea of Rousseau's political philosophy. ${ }^{58}$ According to Neuhouser, the general will, in Rousseau's theory, functions as "an embodiment as well as a precondition of such freedom" to secure, or realize, the freedom of individual freedom. ${ }^{59}$ That general will concerns the public interest, contradicting to the particular will of each individual. Rousseau reconciles the freedom of individuals and the general will which informs the individuals "what men ought to be" through a "nonauthoritarian educative authority", ${ }^{60}$ and the educative authority's "highest ambition is to wither away after injecting its knowledge into beings who become free in the course of time". ${ }^{61}$ The

\footnotetext{
${ }^{53}$ Rousseau, Discourse on Political Economy and The Social Contract, at xii

${ }^{54}$ Rousseau, Discourse on Political Economy and The Social Contract, at xii

${ }^{55}$ Rousseau, Discourse on Political Economy and The Social Contract, at 54

${ }^{56}$ Rousseau, Discourse on Political Economy and The Social Contract, at 55

${ }^{57}$ Rousseau, Discourse on Political Economy and The Social Contract, at 56

${ }^{58}$ Patrick Riley, 'Rousseau's General Will' in P Riley (ed), The Cambridge companion to Rousseau (Cambridge University Press, Cambridge; New York 2001) 124-53

${ }^{59}$ Frederick Neuhouser, 'Freedom, Dependence, and the General Will' (1993) 102 philrevi The Philosophical Review 363-95, at 363

${ }^{60}$ Riley, 'Rousseau's General Will', at 126

${ }^{61}$ Riley, 'Rousseau's General Will', at 126-7
} 
role of this educative authority reveals the existing gap between what men are and what men ought to be, the gap necessitating the educative authority; meanwhile the plural conception of what men are/want and the singular idea of "what men ought to be" expose what the educative authority needs to reconcile: the homogenization of the diversified and contradictory wills of the particulars. Through such a "nonauthoritarian educative authority" as Riley puts it, it produces the norm of "public morality", ${ }^{62}$ a morality ensuring that "every particular will is in accordance with" the general will, ${ }^{63}$ forming the love of one's country. ${ }^{64}$ With the concept of virtue, Rousseau creates a series circuits empowering the public morality expressed by the general will, the conformity of particular will to general will, and virtue of particular individual, and the execution of general will. Yet, without that "nonauthoritarian educative authority", the series circuits are not connected to electricity thus not functioning, at all. The general will, without the actual effect and the theoretical hypothesis of the educative authority, is left with the tension between majority and minority. While Rousseau justifies the obligation of "the minority to submit to the choice of the majority", and "the votes of a hundred who wanted a master to be binding on ten who did not", ${ }^{65}$ through the prior covenant established at the point of unanimity, this prior covenant might have never existed if the educative authority never took place. Without the educative authority and its social impact, the disagreement between particulars and the majority of a group will lead to the enforcement of the will of the majority. Rousseau writes that "if anyone refuses to obey the general will he will be compelled to do so by the whole body", ${ }^{66}$ that whole body is the majority in practice. When discussing the administration of property, recognizing that "the right of property is the most sacred of all citizens' rights" and "property is the true foundation of civil society", ${ }^{67}$ Rousseau considers everyone's contribution to public needs (tax being the modern version of that contribution), shall be legitimate, thus "must be voluntary... through the general will by majority vote, following a proportional tariff which would prevent the imposition being in any way arbitrary." Indeed, the voluntariness which forms the general will shall be the decider of that portion of individual's contribution to the society if educative authority had functioned to form a society ruled by virtue, yet without the educative authority, it is rather a direct form of the violence of the majority. The status of the hypothetical educative authority as the precondition of the theory leads to scepticism of

\footnotetext{
${ }^{62}$ Rousseau, Discourse on Political Economy and The Social Contract, at 14

${ }^{63}$ Rousseau, Discourse on Political Economy and The Social Contract, at 14

${ }^{64}$ Rousseau, Discourse on Political Economy and The Social Contract, at 18

${ }^{65}$ Rousseau, Discourse on Political Economy and The Social Contract, at 54

${ }^{66}$ Rousseau, Discourse on Political Economy and The Social Contract, at 58

${ }^{67}$ Rousseau, Discourse on Political Economy and The Social Contract, at 25
} 
the existence of that nonauthoritarian theory. Who is there to decide if the educative authority had injected its wisdom into beings? Rousseau distinguishes the popular form of public economy and tyrannical form, ${ }^{68}$ yet who is to decide and change if the political economy in existence is one with contradictory wills and interests between the government and the people? The impossibility of deciding on the existence of the educative authority leaves Rousseau's theory with the contradiction between the general will claiming to be the will of the political body, and it being the will of the majority.

Rousseau argues that "the most general will is also the most just, and that the voice of the people is truly the voice of God". ${ }^{69}$ The question, entailed by the contradiction between the will of majority and of minority, is: it is "just" for whom, and "most general" in whose standards? Though claimed as a general will, rhetorically indicating it is not limited to any class, field, that it is miscellaneous, it is de-facto the will of the majority. In contemporary context, it is a majority "as a continuation of the politics of war and economic struggle, as a legitimating distraction from the effort to remake those politics or reframe that struggle, and as an effort to institutionalize the ideology of a particular time and place as universal."70

The concept of public participation resonates with general will, that through participating in environmental decision-making, individuals will get the decision that expresses the general will. With the rhetoric "public", it entails a public as the people, for the people, while neglecting the rights and interests of the minority in that public, i.e. of those with dissenting opinions. Such a neglect contradicts the underlying claim of protecting each and every individual's right to participate in environmental decision-making. The contradiction with the concept of public participation reveals that the right to information and involvement is not adequately protected: having the procedure for participation does not equal to the protection of the right to participation; the right of those with dissenting opinions, the minorities by numbers, are not protected because the "public" in "public participation" is the majority of a group instead of every individual. In the legal language, the "public" in public participation refers to, for example as Agenda 21-Section III identifies, women, youth, indigenous and local populations, non-governmental organizations, local authorities, workers, business and industry, scientists, and farmers. While researches have tried to ideally exhaust all the possible actors outside the authority, considering that whoever may be

\footnotetext{
${ }^{68}$ Rousseau, Discourse on Political Economy and The Social Contract, at 9

${ }^{69}$ Rousseau, Discourse on Political Economy and The Social Contract, at 8

${ }^{70}$ David Kennedy, 'Law and the Political Economy of the World' (2013) 26 Leiden Journal of International Law $7-48$, at 37
} 
affected should "have a say in the determination of their environmental future", ${ }^{71}$ that "foreign citizens and residents should be included", ${ }^{72}$ the top-down structure of the EIA law implies that the public authority, as the initiator of the environmental impact assessment process, has the right to decide who will be included to participate in the process. The authority as the majority has the determinant power over the minority in EIA. The terminology of "public participation", by presenting the joint-involvement of private actors in decision-making, neglects the fact that sovereign states are the sole authority domestically, the absolute majority, hence the only ultimate decision-maker. Principle 23 of 1982 World Charter for Nature provides that "all persons, in accordance with their national legislation, shall have the opportunity to participate". ${ }^{73}$ The theoretical contradiction with the concept of public participation is the reason for the emphasis there, saying "in accordance with their national legislation".

\section{IN APPRAISE OF INFORMAL PARTICIPATION}

The inadequacy of the existing legislations in protecting the right to information and involvement is provided above. While the ecological vulnerability along the Belt necessitates the protection of the right, how to adequately do so?

Informal participation, leading to the protection of the right to information and involvement, offers a possible approach to the protection of the right. ${ }^{74}$ In the context of the Silk Road Economic Belt, the Chinese practice of informal participation in environmental decision-making, while not been adequately researched on, are of essential value. OBOR is essentially a China-centered project, and the infrastructure projects are either directed by, or with the participation of, Chinese industries. The following part introduces a case study in China, which shows the informal participation of private actors, and the dynamic as well as responsive form of environmental governance.

\section{The PM2.5 case}

PM2.5, as a specific standard in Ambient Air Quality Standards, gained the non-governmental actors' attention in Beijing, after the haze enveloped Beijing in Oct and Nov, 2011, starting from 30 Oct. The daily air quality report released by the Beijing Environmental Protection Bureau(BEPB)

\footnotetext{
${ }^{71}$ Kiss and Shelton, Guide to international environmental law, at 102

${ }^{72}$ Donald K. Anton, Environmental protection and human rights, at 381

${ }^{73}$ United Nations General Assembly, World Charter for Nature (1982) <http://www.un.org/documents/ga/res/37/a37r007.htm> accessed 28 Dec 2016

${ }^{74}$ Glenn S. Johnson Robert D. Bullard, 'Environmentalism and Public Policy: Environmental Justice: Grassroots Activism and Its Impact on Public Policy Decision Making' (2000) 56 Social Issues 555-78
} 
said that the air of Beijing was only "slightly polluted". ${ }^{75}$ In the meantime, the air quality data released by the American Embassy in Beijing which includes the data of PM2.5 described the air quality as "extremely dangerous". ${ }^{76}$ On 31 Oct, the Air Pollution Index (API) released by BEPB was 132, while the API measured by the American Embassy was 307, and the PM2.5 Standard was $257 \mu \mathrm{g} / \mathrm{m}^{3} .77$

BEPB responded to the difference between air quality releases, saying that they were based on different methods of calculating. In the Ambient Air Quality Standards of China (AAQS), ${ }^{78}$ adopted in 1982 and revised in 1996 and 2000, ${ }^{79}$ PM 2.5 is not included in the data released as pollutants. Pollutants under monitoring in $A A Q S$ include: $\mathrm{SO}_{2}$, TSP, $\mathrm{PM}_{10}, \mathrm{NO}_{\mathrm{x}}, \mathrm{NO}_{2}, \mathrm{CO}, \mathrm{O}_{3}, \mathrm{P}_{\mathrm{b}}, \mathrm{B}[\mathrm{a}] \mathrm{P}, \mathrm{F}$. The National Ambient Air Quality Standards (NAAQS) ${ }^{80}$ of USA, which was used by the American Embassy to release the Air Quality Index, includes PM2.5 as a standard.

\footnotetext{
${ }^{75}$ Complied by Caixin, 'Beijing Releases PM2.5 Air Quality Readings' CaixinOnline (21 Jan 2012) <http://english.caixin.com/2012-01-21/100350762.html> accessed 28 Dec 2016.

76 新华报业网扬子晚报：PM2.5 事件回顾[Xin Hua Bao Ye Yang Zi Wan Bao: PM2.5 Shi Jian Hui Gu] (Complied by Yangzi News, Xinhua News Net, A Review of PM2.5 Event, 30 Mar 2012) <http://js.xhby.net/system/2012/03/30/013047651.shtml> accessed 26 Dec 2016
}

77 中国知识产权网综合, 空气污染（中） [Zhong Guo Zhi Shi Chan Quan Wang Zong He, Kong Qi Wu Ran (Zhong)] (Complied by Chinese Intellectual Property Net, Air Pollution (mid), 10 Nov 2011) <http://www.cnipr.com/news/dailykeyword/201111/t20111110_138241.html> accessed 26 Dec 2016

${ }^{78}$ The Ambient Air Quality Standards of China came into force on Oct 1, 1996, and was repealed on Jan 1, 2016. Related information about the Ambient Air Quality Standards is available at the official website of Ministry of Environmental Protection of the People's Republic of China, <http://kjs.mep.gov.cn/hjbhbz/bzwb/dqhjbh/dqhjzlbz/199612/t19961206_67502.htm>accessed 26 Dec 2016

${ }^{79}$ Though the Ambient Air Quality Standards was firstly published in 1982, the Atmospheric Pollution Prevention Act of PR. China was published in 1987, and the Environmental Protection Law of PR. China was published in 26 Dec 1989 and came into force at 1990. The Atmospheric Pollution Prevention Act of PR. China was revised in 1995, following which the Ambient Air Quality Standards was revised in 1996. The Atmospheric Pollution Prevention Act of PR. China was again revised in 2000, together with which the Ambient Air Quality Standards was revised in 2000.

${ }^{80}$ The National Ambient Air Quality Standards (NAAQS) in the USA was set by EPA, required by the Clean Air Act, Title 42, Chapter 85 of United States Code. According to the Clean Air Act, there are two types of national Ambient Air Quality Standards, the primary and secondary standards. The primary standards provide public health protection, including protecting the health of sensitive populations such as asthmatics, children, and the elderly. The secondary standards provide public welfare protection, including protection against decreased visibility and damage to animals, crops, vegetation, and buildings. According to the National Ambient Air Quality Standards in the USA, there are six principal pollutants, called the criteria pollutants: Carbon Monoxide (final rule cite: 76 Federal Register 54294, Aug 31, 2011) (Available at: http://www.gpo.gov/fdsys/pkg/FR-2011-08-31/html/201121359.htm (Last visited: 5 Apr, 2013)), Lead (final rule cite: 73 Federal Register 66964, Nov 12, 2008) (Available at: http://www.gpo.gov/fdsys/pkg/FR-2008-11-12/html/E8-25654.htm (Last visited: 5 Apr, 2013)), Nitrogen Dioxide (final rule cite: 75 Federal Register 6474, Feb 9, 2010)( Available at: http://www.gpo.gov/fdsys/pkg/FR2010-02-09/html/2010-1990.htm (Last visited: 5 Apr, 2013)), Ozone (final rule cite: 73 Federal Register 16436, Mar 27, 2008) (Available at: http://www.gpo.gov/fdsys/pkg/FR-2008-03-27/html/E8-5645.htm (Last visited: 4 Apr, 2013)), Particle Pollution (final rule cite: 78 Federal Register, Jan 15, 2013)( Available at: http://www.gpo.gov/fdsys/pkg/FR-2013-01-15/pdf/2012-30946.pdf (Last visited: 4 Apr, 2013)), and Sulfur Dioxide (final rule cite: 75 FR 35520, Jun 22, 2010) (Available at: http://www.gpo.gov/fdsys/pkg/FR-2010-0622/html/2010-13947.htm (Last visited: 4 Apr, 2013)). According to the final rule on national Ambient Air Quality 
The haze and the difference between the API released by BEPB and the American Embassy attracted large attention of the general public. ${ }^{81}$ There were huge number of posts concerning the haze on SinaWeibo ${ }^{82}$ in China, with famous posters include YAO Chen, a popular movie star with the largest number of followers on SinaWeibo at that time (has 32,222,254 followers on SinaWeibo ${ }^{83}$ ), and PAN Shiyi, Chairman of SOHO China, the largest prime office real estate developer in China (has 14,123,456 followers on SinaWeibo ${ }^{84}$ ). The private actors called for the incorporation of PM2.5 Standard in the AAQS.

At mid-Nov 2011, the Ministry of Environmental Protection of China released the second draft of the Letter seeking Public Opinion on the Ambient Air Quality Standards (Letter Seeking Opinions) and third draft of the Ambient Air Quality Index technical requirements inviting comments from the public. The first draft of the Letter Seeking Opinion was released on 18 Dec, 2010. On 21 Dec, 2011, minister of Ministry of Environmental Protection of China released the time schedule for the auditing of PM2.5 in different areas of China. On 30 Dec, 2011, the revised Ambient Air Quality Standards was approved by the executive meeting of the Ministry of Environmental Protection of China in-principal. ${ }^{85}$ On 29 Feb, 2012, the executive meeting of the State Council agreed to release newly revised Ambient Air Quality Standards (2012). ${ }^{86}$

The newly revised Ambient Air Quality Standards (2012) was officially published by the Ministry of Environmental Protection of China on 29 Feb, 2012, ${ }^{87}$ and came into effect nationally

Standards for particulate matter, the particulate matter standards have been updated. When the Oct 2011 event happened, the standard used was the 71 Federal Register 61144, adopted on Oct 17, 2006, and according to the particulate matter standard, 24-hour standard for primary and secondary PM2.5 is 35 $\mathrm{g} / \mathrm{m} 3$, while the annual standard for PM2.5 is $15.0 \mu \mathrm{g} / \mathrm{m} 3$. During the Oct 2011 fog, the PM2.5 Standard was 257 $\mu \mathrm{g} / \mathrm{m} 3$, which was far beyond the standard from the 2006 rule on national Ambient Air Quality Standards for particulate matter.

81 郭绪 (Xu Guo), '环保部门专家: PM2.5 入空气质量监测时机不成熟 [Huan Bao Bu Men Zhuan Jia: PM2.5 Ru Kong Qi Jian Ce Shi Ji Bu Cheng Shu] (Environmental experts: it is not yet the time to add PM2.5 into Ambient Air Quality Standards)' 法治周末(The Rule of Law Weekend) (9 Nov 2011) <http://news.ifeng.com/shendu/fzzm/detail_2011_11/09/10510979_0.shtml> accessed 26 Dec 2016

${ }^{82}$ Sina Weibo is a Chinese online posting website, similar as Twitter <http://www.weibo.com> accessed 26 Dec 2016

${ }^{83}$ Chen Yao's Weibo page <http://www.weibo.com/yaochen> accessed 14 Dec, 2012

${ }^{84}$ Shiyi Pan's Weibo page <http://www.weibo.com/panshiyi> accessed 14 Dec, 2012

${ }^{85}$ Official website of the Central People's Government of the People's Republic of China <http://www.gov.cn/ldhd/2012-02/29/content_2079351.htm> accessed 26 Dec 2016

86 扬子晚报 [Yang Zi Wan Bao] (Yangzi Evening Paper), 'PM2.5 事件回顾 [PM2.5 Shi Jian Hui Gu] (A Review of PM2.5 Event)' 扬子晚报 [Yang Zi Wan Bao] (Yangzi Evening Paper)

(<http://news.ifeng.com/gundong/detail_2012_03/30/13544749_0.shtml> accessed 26 Dec 2016

${ }^{87}$ Ambient Air Quality Standards (2012), official website of the Ministry of Environmental Protection of the People's Republic of China <http://www.mep.gov.cn/gkml/hbb/bgg/201203/t20120302_224145.htm> accessed 26 Dec 2016 
in 2016. The Ministry of Environmental Protection required cities and areas national-wide to implement the new AAQS before the Ambient Air Quality Standards (2012) came into effect nationally in 2016, according to the Guidance on the Promotion of Air Pollution Joint Prevention and Control Work to Improve Regional Air Quality released by Office of the State Council No.33 (2010). After the publication of the new AAQS, the First Phase of the Program on Implementation of the New Ambient Air Quality Standards was published by the Office of the Ministry of Environmental Protection on 21 May, 2012, ${ }^{88}$ and in the Annex of the First Phase of the Program on Implementation of the New Ambient Air Quality Standards, a list of cities that would implement the AAQS (2012) as well as numbers of PM2.5 monitoring sights in each city were provided. Beijing is in the list. The Second Phase of the Program on Implementation of the New Ambient Air Quality Standards was published by the office of the Ministry of Environmental Protection on 22 Mar, 2013, ${ }^{89}$ and more cities for implementation of the new AAQS were listed in the annex. In Beijing, the Municipal Environmental Protection Bureau planned, that from 28 Sep, 2012, 20 monitoring stations would run in Beijing, and the monitoring data would be on the Beijing Air Quality Monitoring Platform for immediate release, ${ }^{90}$ and from 1 Jan, 2013, air-quality-monitor would start running according to the Ambient Air Quality Standards revised in 2012, and further 12 places of monitoring would be established.

\section{Informal participation in the PM2.5 case}

Non-governmental actors initiated the process by requesting for the release of PM2.5, and managed to attract the attention of the governmental authority through internet and other channels: the posts on social media SinaWeibo by Yao Chen and Pan Shiyi; the survey conducted by SinaWeibo on whether to introduce PM2.5 as mandatory environmental standards or not, which attracted more than 40,000 votes with 38447 (91.1\%) votes for the introducing of PM2.5, and 27068 retweets of the survey; ${ }^{91}$ and individual efforts. An example of individual efforts is YU Ping's recourse to appeal. On Oct 2011, YU Ping, a Beijing local citizen, applied for PM2.5 information disclosure from BEPB; after 15 days, YU received a reply from BEPB, with his request been rejected; on 26 Dec, YU applied again for the disclosure of the PM2.5 data from 19 Nov to 26 Dec. The BEPB

\footnotetext{
${ }^{88}$ First Phase of the Program on Implementation of the New Ambient Air Quality Standards, official website of the Central People's Government of the People's Republic of China <http://www.gov.cn/zwgk/201205/24/content_2144221.htm> accessed 26 Dec 2016

${ }^{89}$ Second Phase of the Program on Implementation of the New Ambient Air Quality Standard, official website of the Ministry of Environmental Protection of the People's Republic of China <http://www.zhb.gov.cn/gkml/hbb/bgt/201303/t20130328_250063.htm> accessed 26 Dec 2016

${ }^{90}$ Beijing Municipal Environmental Monitoring Center, <www.bjmemc.com.cn> accessed 26 Dec 2016

${ }^{91}$ Voting result of online-survey on introducing PM2.5 as a standard in Ambient Air Quality Standards <http://vote.weibo.com/vid=1127783> accessed 26 Dec 2016
} 
responded on 6 Jan, 2012 by making the PM2.5 data of the past 10 years open, but the PM2.5 data of the requested period was still missing. BEPB replied that the they do not have the date of the requested period. ${ }^{92}$

Throughout the PM2.5 case, non-governmental actors and the governing bodies formed a responsive system of interaction. This responsive system of interaction was initiated by the informal participation of individuals by, for instance, creating pressure on the internet, and attracting public authority's attention through individual's application handed to the decision-maker. With the informal participation, the governing bodies released Letter Seeking Opinions as a response to the informal participation, and soon a new regulation on the matter was released. The effectiveness of informal participation is shown in PM2.5 case, that the first draft of The Letter seeking Opinions was released on $18 \mathrm{Dec}, 2010$, and in the first draft, PM2.5 was already listed as one of the standards been monitored ${ }^{93}$ however, the first draft was there seeking for opinions from units and universities for a year. At mid-Nov 2011, Ministry of Environmental Protection of China released the second draft of the Letter Seeking Opinions and the third draft of Ambient Air Quality Index technical requirements, right after the informal participation of the individuals since the haze enveloped the city on 30 Oct, 2011.

Through the informal participation of individuals in environmental decision-making, the public contribute "to promoting public environmental interests". ${ }^{94}$ The case presented here, with the adoption of PM2.5 in the Ambient Air Quality Standards, shows the impact of informal participation in environmental decision-making. When the environment-related-information is not available, informal participation facilitated the process of the release of the information. Particularly, the environmental information requested is included in regulations. While the formal legislation protecting the right to information and involvement, the EIA procedure, allows the public to participate when the governmental authority allows and provides the channel for participation, informal participation in the case of PM2.5 effectively protect the right.

\section{Informal participation elsewhere}

\footnotetext{
92 沈栖 [Xi Shen], '面对环保部门拒绝公开信息 [Mian Dui Huan Bao Bu Men Ju Jue Gong Kai Xin Xi] (Facing the Rejection of Information Disclosure)' 上海法治报 [Shang Hai Fa Zhi Bao] (Shanghai Rule of Law Newspaper) (<http://newspaper.jfdaily.com/shfzb/html/2012-08/27/content_870920.htm> accessed 26 Dec 2016

93 The first draft of The Letter seeking Ambient Air Quality Standards is on the official website of the Ministry of Environmental Protection of the People's Reupublic of China <http://www.zhb.gov.cn/gkml/hbb/bgth/201011/t20101130_198128.htm> accessed 26 Dec 2016

${ }^{94}$ Daniel Bodansky, Jutta BrunnÈe and Ellen Hey, The Oxford handbook of international environmental law (Oxford University Press, Oxford; New York 2007) at 689
} 
The adoption of the Aarhus Convention, as the first part of the paper introduces, exemplifies the active role of NGOs in Central Asia. Informal participation has largely attracted the attention of academic research. ${ }^{95}$ While the PM2.5 case shows the value of informal participation in protecting the right to information and involvement in China, NGOs in environmental governance play a less significant role in China in comparison with it in Singapore. This part gives a brief introduction of informal participation in Singaporean environmental governance, showing the communicative environmental governing system formed by encouraging informal participation in Singapore. While Singapore is not on the Silk Road Economic Belt, the communicative environmental governing system is of referential significance for China.

NGOs and other non-governmental actors are increasingly involved in Singaporean environmental governance through informal participation in environment decision-making, ${ }^{96}$ facilitating the protection of the right to information and involvement in environmental decisionmaking. In Singapore, though the "processes of engagement between government and environmental non-government actors are far from consultative and open", ${ }^{97}$ the NGOs have successfully persuaded the Singaporean government in many environment-related cases. For instance, Nature Society Singapore played an important role in the case of "the conservation of Sungei Buloh". ${ }^{98}$ The increasingly inclusion of NGOs in environmental governance is observed in Singapore, that "reliance on networks and partnerships is emerging" 99 As Francesch-Huidobro observes, "organizations of civil society, NGOs, are an increasingly prominent feature" of governance in Singapore. ${ }^{100}$ While the government plays a critical role in environmental governance, the government and NGOs are forming a partnership through which the government co-opts with NGOs in dealing with environmental issues. Such a partnership is evidenced by institutional arrangements including, as Francesch-Huidobro introduces, the creation of the National Environment Agency out of the Ministry of the Environment, in order "to deal with implementation

\footnotetext{
${ }^{95}$ Stephen P. Depoe, John W. Delicath and Marie-France Aepli Elsenbeer, Communication and public participation in environmental decision making (SUNY Press ; University Presses Marketing [distributor], Albany, N.Y.; Bristol 2011); Michele Merrill Betsill and Elisabeth Corell, NGO diplomacy : the influence of nongovernmental organizations in international environmental negotiations (MIT Press, Cambridge, Mass. 2008);

96 The result of that participation might not always be positive though, as Maria Francesch-Huidobro argues, in the case of NGOs' involvement in environmental governance in Singapore, "outcomes of successive campaigns" might not always be "favorable to the environmental causes", see, Maria Francesch-Huidobro, Governance, politics and the environment : a Singapore study (Institute of Southeast Asian Studies, Singapore 2008) at 287

${ }^{97}$ Francesch-Huidobro, Governance, politics and the environment : a Singapore study, at 287

${ }^{98}$ Francesch-Huidobro, Governance, politics and the environment : a Singapore study, at 287

${ }^{99}$ Francesch-Huidobro, Governance, politics and the environment : a Singapore study, at 286

${ }^{100}$ Francesch-Huidobro, Governance, politics and the environment : a Singapore study, at 291
} 
of environmental protection policies", the establishing of the National Parks Board under the Ministry of National Development, "to deal with nature conservation issues", and the setting up of the Singapore Environment Council "as the environmental NGO umbrella organization". ${ }^{101}$

Through the informal participation of non-governmental actors, environmental governance in Singapore has evolved into a dynamic and cooperative form of governance, involving nongovernmental actors including NGOs, individuals, social network etc, in environmental decisionmaking. It forms a system of communication between the governing authorities and other actors that might be affected in environmental decision-makings. Such a system of environmental governance, this paper suggests, might be of referential value to both domestic Chinese environment-related decision-making, and the protection of the right to information and involvement along the Belt and Road.

\section{CONCLUSION}

The centrality of economic factors in One Belt One Road (OBOR) is confirmed in the Vision and Actions on Jointly Building Silk Road Economic Belt and 21st-century Maritime Silk Road, which also informs the difficulty in defining the scope and framework of OBOR. The openness and economy-driven design of OBOR frames it more as "informal, cooperative and loosely structured with a soft approach to rules and boundaries". ${ }^{102}$ This is different from other development institutions like the World Bank, and other international regimes designed to strengthen cooperation, like WTO, TPP and so on. Such an informal and cooperative structure entails, thus, heavy reliance on local and regional rules. While proactive solutions are needed to harmonize the legal and policy orientation of the projects in transnational legal settings, ${ }^{103}$ those rules are harmonized, by and large, only to facilitate economy-driven projects. The tendency of focusing on the economic side of the Belt leaves other aspects of the Belt largely neglected. Indeed, the Silk Road Economic Belt is about the economy, yet with joint infrastructure and other projects taken place, subsequently accompanying issues have emerged, among which the environmental protection in the process of setting up infrastructure and other projects along the Belt.

The geographical regions of the Belt have vulnerable ecological environments. Each infrastructure project has an evitable impact on the environment. The history of and the current

\footnotetext{
${ }^{101}$ Francesch-Huidobro, Governance, politics and the environment : a Singapore study, at 291

102 Lvy Buche Jean-Pierre Lehmann, Marc Laperrouza, Shuaihua Cheng, Lu Xiankun, Jean-Guy Carrier, Marion Jasen, Félix Sutter, Yeroen Van der Leer, 'One Belt- One Road: China's Re-Engineering of the Global Business Environment'

103 Ahmad Ghouri, 'Towards Greater Integration? Legal and Policy Directions of Chinese Investments in Pakistan on the Advent of the Silk Road Economic Belt' (2016) 4 Chin J Comp Law The Chinese Journal of Comparative Law 36-68
} 
political situation in the region of the Belt add another dimension to environment protection. The predominantly economic reasons driving most projects both inside and outside China have engendered much criticism from those advocating environmental protection and human rights. In Central and West Asia, many countries are facing the tension between rapid economic development and the need for better environmental protection.

Approaching environment protection along the Belt through the rights approach untangles the complex issue of the environmental and social impact of infrastructure and other projects along the Belt. Human rights and environment protection are different issues, yet they protect certain common social values. In the context of the Belt, by focusing on the right to information and involvement, this paper explores ways for the protection of this right and essentially, those social values even if formal legislation is not satisfactory.

The right to information and involvement is protected through domestic EIA legislation. An introduction of the EIA law of the countries and regions along the Belt is out of the scope of inquiry of this paper. The example of Chinese EIA legislation is sufficient to exemplify the top-down structure of EIA, a structure in which the governing bodies have the authority in deciding what are the environmental issues to the discussed, when the issues shall be discussed, and who shall be involved through what means in decision-making process. The evidence of the participation of citizens in environmental decision-making, in for example Poland, reveals the inadequacy of the EIA legislation in protecting this right. A statistical analysis on the capacity of EIA legislation in protecting the right reveals inadequacy.

Adding to the critique of the inadequacy of formal legislations in protecting the right, public participation, the (international) environmental principle protecting the right to participate, including the right to information and involvement, is embedded with a theoretical contradiction. The "public" in "public participation" is not the people, the general public, but rather the majority with endowed authority. The rhetoric of "public" contradicts with the neglect of (groups) of individuals in decision-making. The EIA legislation is a top-down process, giving the governing bodies the power to decide whom to be included in discussing what issues. The governing body is thus the majority, with the power to neglect the rights of the individuals as the minority. The contradiction in the concept of "public participation" repeats the contradiction in the concept of "general will” by Rousseau. Through a critique of Rousseau's "general will”, this paper reveals the theoretical contradiction in "public participation".

The role of informal participation in protecting the right to information and involvement lead to an appraise of informal participation. The PM2.5 case shows the value of informal participation in China. The Singaporean experience of informal participation, in particular, presents a responsive 
dynamic between the governing bodies and non-governmental actors, forming an environmental governance. Informal participation facilitates the protection of the right.

In the context of the belt, countries along the Belt largely overlap with the parties to the Aarhus Convention, which protects the right to information and involvement. A social and historical exploration of the process of adoption of the Aarhus Convention reveals that most of the Belt countries have a strong tradition of participation in public debate by NGOs. Environmental activists' involvement in social and environmental events is forming an active civil society in Central Asia. ${ }^{104}$ One of their latest success being Aral Sea International Committee and some foreign NGOs' effort to include local NGOs in the donor conferences for the Aral Sea Basin Programme. ${ }^{105}$ The alliances between local activists in the region and international activists exert pressure from outside on domestic governments. ${ }^{106}$ Transitional alliances in Central Asia also "provide an important role for domestic institutions in shaping policy outcomes from within", ${ }^{107}$ and the activists are playing a significant role in interacting with the local governments in environmental decision-making. The strong civil society in the region along the Belt provides the fertile soil for encouraging informal public participation. While informal participation does not always lead to a desired result, as the Singaporean experience of the participation of NGOs in environmental governance shows, with the right to information and involvement inadequately protected under (international) environmental law, informal participation could facilitate the protection of the right along the Belt.

\footnotetext{
${ }^{104}$ Erika Weinthal and Kate Watters, 'Transnational environmental activism in Central Asia: the coupling of domestic law and international conventions' (2010) 19 Environmental Politics 782-807

105 Weinthal and Watters, 'Transnational environmental activism in Central Asia: the coupling of domestic law and international conventions'

${ }_{106}$ Margaret E. Keck and Kathryn Sikkink, Activists beyond borders : advocacy networks in international politics (Cornell University Press, Ithaca, N.Y. 1998)

107 Weinthal and Watters, 'Transnational environmental activism in Central Asia: the coupling of domestic law and international conventions', at 783
} 